\title{
Reflecting on Teaching Pragmatics for Graduates Students
}

\author{
Hendi Pratama ${ }^{1}$, Widya Amalia ${ }^{2}$ \\ \{hendipratama@mail.unnes.id'1 ,widyaamalia40@students.unnes.ac.id²\} \\ Universitas Negeri Semarang, Kampus Sekaran-Gunungpati, Semarang ${ }^{1}$, Universitas Negeri \\ Semarang, Kampus Sekaran-Gunungpati, Semarang ${ }^{2}$
}

\begin{abstract}
Pragmatics deals with language in use and the context in which it used. We can convey meaning through communication by using pragmatics. Teaching pragmatics means considering the relationship between the variety of speakers and many social factors which come up with the dynamic growth of the language itself. Fostering pragmatics competence in language teaching should be done gradually since learning pragmatics is not only about acquiring a new language competence but also learning its implementation in different context and levels of intercommunication. As a result, the learners must accomplish the mastery of pragmatics and reflect it into their daily communication. This paper reflects the experience in the class of pragmatics for graduate students. It is a qualitative based research which examines students' mastery and the implementation of pragmatics in their conversation. Moreover, this paper portrays the relation between pragmatics and language teaching through teaching and learning activity. After all, at the end of the class, the learners must reflect on to what extent pragmatics is important in their daily communication.
\end{abstract}

Keywords: Pragmatics, Language Teaching, Daily Communication.

\section{Introduction}

Pragmatics is a study of languages used by speakers and speech partners to convey intentions in a conversation based on the context. Pragmatics as part of communication competence is very important to be taught to students to strengthen their communicative competence as a language learner. Nowadays most language learners are not learning a language as a communication tool but as knowledge or theory of language [1]. This causes many discoveries that after 9 years of elementary and secondary education, students are still unable to use the language they learn to communicate. On the contrary, language plays an important role in life as a tool to communicate with others.

Pragmatics investigates meaning that is bound to the context underlying the use of the language in communication [1]. It can be concluded that the real meaning of a speech is influenced by the context. Communication can be said to be effective if the message and purpose of the speaker can be conveyed and understood by the interlocutor. However, not all speakers convey clearly or explicitly what they mean. Therefore, it can sometimes trigger misunderstandings, because people can interpret it differently or even contrary to what they mean. Therefore, it is very important to see and relate the context to the conversation so as not to cause misunderstanding. Yule [2] states that having a good speech from the convention allows 
the speaker to establish and maintain effective and accurate communication and understand each other clearly.

Pragmatics competence is beneficial for students both their professional and personal life. Fostering communicative competence through teaching pragmatics to postgraduate students is not only the major purpose but also as the advanced way to strengthen both their communicative and academic competence. Kasper [3] emphasized that pragmatics helps learners to use language appropriately based on the contextual factors.

\section{Literature Review}

\subsection{Pragmatics}

Many linguists propose various definitions of pragmatics. Yule [2] defines pragmatics as the study that concerns with the meaning communicated by a speaker (or writer) and interpreted by a listener (reader). This type of study necessarily involves the interpretation of what people mean in a context in which the context influences what they say is. It requires a consideration of how speakers organize what they want to say in with whom they are talking to, where, when, and under what circumstances.

According to Griffith [4], pragmatics is about the use of utterances in context, about how people manage to convey more than what is encoded by the semantics of sentences. Pragmatics builds on what is semantically encoded in the language. That is the point which makes them different. Further, he explains that semantics is the study of the "toolkit" for meaning, while pragmatics is concerned with the use of these tools in meaningful communication. Pragmatics is about the interaction of semantic knowledge with our knowledge of the world, considering contexts of use.

In conclusion, pragmatics is a study which is concerned with language and its users in a certain context. The users refer to both speaker and hearer. The meaning of the utterances delivered by the speaker is not only confined to the meaning from the speaker but also the interpretation from the hearer. The contexts in which the conversation takes place also influence the interpretation of the meaning. The different context will lead to different interpretation. Therefore, the scope of pragmatics is wide. It covers many other principles such as deixis, speech acts, presupposition, cooperative principles, conversational implicature, and politeness.

\subsection{Speech acts}

Speech acts are one of the Pragmatic sciences which is most often discussed or researched by observers of linguistics [1]. Pragmatics defines as the study of meaning in the context between the speaker and the hearer which the speaker delivers utterance and the hearer interprets the utterance. It can be said that pragmatics is logical to study and study of language use in society. The speaker's utterance deals with speech act and speech act is an action performed via utterance. Yule \& Stalnaker [5] state action of utterance can be formed such as apology, complaint, compliment, invitation, promise, or request. Speech act is an utterance that can be used in different functions in communication and to accomplish particular purposes. Austin [6] distinguished the types of speech acts into three categories: locutionary acts (the utterance of saying something), illocutionary (the act performed by utterance), perlocutionary (the effect of the utterance which is achieved by the hearer). 
Yule \& Stalnaker [5] state that speech act can be distinguished in three basics of the sentence. Those can be recognized into three differences forms: declarative, interrogative, and imperative. The structural forms (declarative, interrogative, and imperative) have a relation with three general functions (statement, question, and command/request). The form of declarative is marked by subject and followed by verb/auxiliary/modal. Then, the form of an interrogative is marked by a question mark. In interrogative is preceded by WH question/verb/modal and followed by a subject. Eventually, imperative is a sentence to express a command. For instance, close the door.

Speech act relates two approaches: direct and indirect speech act. Yule \& Stalnaker [5] state direct speech act has a relation between structure and function directly, and indirect speech act has an indirect relation between structure and function. However, Searle [7] points out five general functions of speech act and those are as follows representative, commissive, directive, expressive, and declaration.

\subsection{Implicatures}

Implicatures are meanings that are conveyed but not explicitly pronounced [1]. In a conversation, a speech has certain implications that are not stated explicitly. In a simple explanation from Horn and Ward [8], implicature is a component of a speaker which is an aspect of what is meant without having to be part of what is said. They also say that the implicature does not depend on the speech partner or sentence, it differs from the non-logical conclusion that the speech partner assumes.

The question that often arises is where we must distinguish between what is conveyed by what is meant. Grundy [9] asserts that; (1) context plays a very important role in influencing the meaning meant in an utterance, and (2) understanding the speaker helps us in trying to guess the meaning.

Pratama [1] states that there are two types of implicature; conventional implicature and conversational implicature. He added that both were equally struggling with the true meaning of a teaching, only the difference was that conventional implicatures always used the same type of implicature in the context of any situation. While the conversational implicature has a more varied variety.

\subsection{Politeness}

Brown and Levinson [10] categorized four politeness strategies. The first strategy is called baldly on record without redressive action that directly sticks to the original utterance. The speaker does the FTA thoroughly and obviously since the speaker believes that there are several occasions which force someone to deliver their utterances directly. For instance, if there is an emergency and it forces the speaker to directly produce an utterance. The second strategy is called positive politeness strategy. It gives an emotional impact toward the hearer, it shows how the speaker and the hearer share their values. The third strategy is called negative politeness strategy which emphasizes building personal awareness without any pressure, apologizing to each other, and avoiding interfering with the freedom of the speakers. This strategy builds such a valuable behavior since they can respect each other without imposing the hearer. The fourth strategy is called off record. In this strategy, the utterances are in the form of indirect speech. Moreover, the speaker performs the implicit utterances.

According to Cruse [11] politeness is minimizing the negative effects that can be caused by a person against others and at the same time trying to maximize positive effects. There Cruse also mentioned that there were 2 types of politeness: 1) politeness based on speakers who required that speakers not say something that could cause a negative impression of themselves, 
and 2) politeness based on speech partners who tried to reduce expressions that were considered impolite.

This paper portrays to what extent pragmatics involves and is beneficial in our academic and daily communication. The gathered data is analyzed under a qualitative method.

\section{Methodology}

This article used a qualitative method in gathering the data. Qualitative method emphasizes more in data analysis. The researcher used an online questionnaire as the main instrument to collect the data. This research is done under three research questions as follows,

1) To what extent postgraduate students' understanding of pragmatics after having the course for a semester?

2) To what extent does a pragmatics course affect postgraduate students' learning process or the way they teach English towards their students?

3) To what extent does a pragmatics course affect postgraduate students' daily communication?

Based on those three questions, the researcher found how pragmatics give a certain impact toward the students.

\section{Finding and Discussion}

To answer the first question, the researcher took 70 post-graduate students as the respondents of this research. Most of the students understand what pragmatics is after having the course in a semester. They find that learning pragmatics fulfil their curiosity about it. Student 2 (S2) re-explain what pragmatics is in his simple language based on his understanding after attending a pragmatics course.

\subsection{Postgraduate Students' Understanding about Pragmatics}

There are 44 students can define pragmatics based on their understanding. For instance, Student 18 (S18) who re-defined pragmatics as a linguistic study that studies how linguistic units are used in communication, we need pragmatics to understand the meaning of someone's hidden linguistic behavior. It could be referred to that pragmatics investigates what is unsaid. Student 72 (S72) re-defined Pragmatics as a branch of linguistics concerned with the use of language in social contexts and the ways people produce and comprehend meanings through language.

Moreover, there are 23 students can define pragmatics in detail and systematically. For example, Student 10 (S10), according to S10, pragmatics is a part of linguistics that studies the intentions of speakers with the help of the context when the speech is spoken. Context can be obtained, for example, by paying attention to the things before and after the speech, or by considering the physical and non-physical aspects of the speech. Then Student 58 (S58) who understands pragmatics as "a branch of linguistics that focuses on analyzing the intentions of speakers with the help of context. In other terms, pragmatic is the science of linguistics that studies the ability of language users to connect speech or sentences with context so that they become appropriate or easily understood speech. The meaning of the context referred to in pragmatic science is all physical and non-physical aspects that accompany speech, for example, the relationship between speakers, the weather, the times and so on. " Besides, there is Student 30 (S30) who concludes (pragmatic definition) based on the two references he cited. Following is the answer from Student 30 (S30): "According to Yule [2] pragmatics is the study of relationship between linguistics forms and the users of the forms. In pragmatics, we study 
people's intended meanings, their assumptions, their purpose, and the kinds of actions that they are performing when they speak. Mey [12] states that pragmatics is the science of language seen concerning its users. Therefore, I can conclude that pragmatics is a study that analyzes the language usage which focuses on the speakers or the users. "

There are still 6 students who are less able to explain the definition of pragmatics correctly. For example, Student 9 (S9) stated that "Pragmatics is a science related to the use of language. This science studies how language is used when communicating/interacting." Student 12 (S12) missed mentioning "context" but was able to give an example of "context" itself. S12: "In general, pragmatics can be interpreted as a study of linguistics about the meaning of the speaker's utterance which is interpreted by the listener or interlocutor. The interpretation of meaning in pragmatics is also based on how close or far the relationship between speaker and listener is. " There is also Student 52 (S52) which simply defines pragmatics as the study of meaning in a language.

A total of 52 students were able to explain the meaning of speech acts appropriately by including the right examples. For example Student 13 (S13) which explains non-speech like this, "Speech acts are utterances performed by speakers to make the listener perceive the meaning or do what the speaker intended. Example: "Wow, I think the Cireng is delicious!" (The speaker intends for the interlocutor (speech partner) to let him taste the food / Cireng belonging to the interlocutor). " Then there is Student 26 (S26) who understands Speech act as a study that discusses how someone expresses an intention to reach someone they are talking to. Usually, the speech act contains a sentence that contains the action desired by the speaker so that the listener understands its meaning. Taken example: The room is hot huh ... Meaning that the speaker here wants the AC in the room to be turned on. Moreover, Student 31 (S31) interpreted speech acts as the use of intention in pronouncing an utterance to invite behavior or physical response from the interlocutor. For example, in an online pragmatic class, all students turn off the audio when entering the class. A lecturer said, "How come the class is quiet like I teach walls." A few moments later, several students turned on their audio and responded to what was asked by the lecturer.

There are still 15 students who are unable to explain the meaning of speech acts correctly even though they have included the right examples. Like Student 15 (S15) who understood speech act as a speech act that had meaning. example: it is five o'clock (this utterance give information to the hearer). Then there is Student 19 (S19) who understands speech acts as a part of language that involves participants in a conversation, its forms such as topics, messages, contexts etc. Example: When I go to college 'I just got stuck in traffic' here my position is to say sorry that I was late in a different language. And Student 47 (S47) interpreted speech acts as speech which not only contains information but also as an act of the speaker. For example, when someone says: "Sorry, I couldn't come yesterday." The sentence also contains the act of apologizing the speaker to the interlocutor.

As many as 6 students were less able to explain the meaning of speech acts correctly and did not include examples. Like Student 4 (S4), which simply explains that speech acts are the study of the meaning in a speech which has the implied meaning of the speaker. Student 14 (S14) described speech acts as a communication process in the form of words or sentences accompanied by certain expressions. In expressing the intent, many ways are used even though the purpose and meaning are the same. There is also Student 52 (S52) who instead of writing examples just mentions the classification of speech acts as follows, utterances uttered by speakers with a specific purpose. Example: commissive or directive speech acts.

Regarding the third question regarding understanding implicature theory, as many as 55 students had understood the implicature theory and were able to provide the right example. This 
can be seen from the answers submitted by students, including Student 3 (S3), he explained the concept of implicature as follows, "The implicature of conversation refers to the indirect meaning in a speech. The purpose of the conversational implicature is to invite listeners to grasp other meanings in the utterances conveyed by speakers. For example A: "How was the movie at the cinema last night?" B: "The air conditioner is cold, it makes me cold". In the above conversation, it is not very good, because it violates the maxim of relevance, between the questions and the answers are in line. however, in the conversation, there is an implicature that invites "A" to grasp the meaning behind the utterance, namely the film is not interesting. " There is also Student 16 (S16) which describes the implicature as the situation between the speaker and the hearer in which what is implied varies according to the context of utterance. For example, A: Will you accompany me to watch the movie? B: Mr.Hendi, my lecturer, just sent me a google form to fill in. The conversational implicature may signal a rejection over an invitation. Student 17 (S17) who defines the conversational implicature as follows: "Conversational implicature refers to the implications of a conversation which are obtained/inferred through recognizing the speaker's intention in a context. For example, A: "I need new shoes to wear for UTBK next month. Let's go shopping in Matahari. " B: "Mall can be a place for coronavirus spread.". From the conversation, we can infer that B refused the idea that A proposed."

The responses to the third question also show that there are 11 students understand implicature theory but have not been able to provide the right example. Some of them are S4, S45 and S52. Student 45 (S45), according to him, conversational implicature is one thing that is studied in the field of pragmatics which refers to the meaning of a literal utterance with meaning from a speaker's point of view which has a different meaning. For example: "How come I'm hungry huh ..." The literal meaning is that the speaker feels hungry. The meaning that the speaker wants to convey is yes, he wants to invite the other person to go eat. Student 52 (S52) states implicature as the meaning contained in an utterance but is not stated directly. Example: Today is very hot, it could mean asking to open the door or asking for drinking water. Meanwhile, Student 4 (S4) has understood the theory but did not write any examples at all.

In addition, 1 student indicated that he did not understand implicature theory even though he was able to provide the right example. Even though Student 38 (S38) has not been able to define the implicature of conversation precisely, the example he wrote is following accordance with the theory of conversational implicatures.

Unfortunately, there are still 6 students who do not understand the implicature theory and have not been able to provide proper examples. For example, Student 15 (S15) explained that conversational implicature is an utterance that is spoken indirectly. For instance: Last night I watch the drama crash landing on you. The drama was very stressful and romantic (the speaker wants the hearer to come to her house to watch together). Then, there is Student 54 (S54) who has missed interpreting the messages in the implied conversational implications and has not been able to include the right examples. Meanwhile, Student 46 (S46) is still unable to define the implicature of the conversation precisely and does not include any examples.

There are 55 students have understood the concept of politeness and can provide the right example. Some of them are Student 1 (S1) and Student 6 (S6). S1 understands politeness as a language strategy to maintain the quality of relationships and avoid things that risk damaging the relationship. S1 can provide 5 examples that accurately represent the five politeness strategies according to Brown and Levinson [10]. S6 defines politeness as the relations between the speaker and the hearer where the speaker try to reduce the impact on an action that may threaten to the hearer. S6 relates politeness in pragmatics to her knowledge of 'upload-upload' 
In Javanese. S6 gives an example of politeness in a conversation between a boss and his / her secretary, the secretary says "May I ask for permission to not work today, sir/mam?"

There are 55 students have understood the concept of politeness and can provide the right example. For example Student 16 (S16) and Student 4 (S4). S16 can describe politeness as a genuine desire to be pleasant to others or as the underlying motivation for an individual's linguistic behavior. However, instead of taking the example of politeness in oral communication, S16 took the example of polite actions as follows "During his successful General Election campaign in 2018, Jokowi undertook various photo opportunities to emphasize how in touch he was with ordinary people." While S4 can define politeness as someone's effort to maintain relationships and avoid conflicts in communication or misunderstanding, S4 has missed an example.

There are 9 students still do not understand the concept of politeness but can provide the right example. Those students are such as Student 19 (S19) and Student 22 (S22). S19 is limited to understanding politeness as a form of good action by someone to certain people. Even though S19 does not understand the theory, he has been able to provide the right example, if this example is translated as "Where would you go, sir/ma'am?" in the context of asking older people for goals. Besides S19, S22 is also limited to understanding politeness as a sub-discipline of pragmatics to an extent of human action to utter or behave politely towards others. Example "Will you be kind enough to tell me where is the mosque?"

There are 9 students still do not understand the concept of politeness but can provide the right example. Student 46 (S46) describes politeness as one of the studies in pragmatics. Then, S46 cites the definition of politeness according to the KBBI without giving an example. The same thing was found in the response of Student 52 (S52), according to S52 politeness is the politeness of speech to whom we are going to talk. The S52 also doesn't include courtesy examples.

4.2 The influence of pragmatics, speech act, implicature and politeness on the way respondents learn or teach English.

As English learners, respondents consider that mastery of pragmatics has had a positive impact on understanding English material because respondents feel they can understand literal and non-literal meanings of a speech delivered by lecturers. Mastery of pragmatics also has a positive impact on improving interpersonal skills. This increase occurred because respondents were able to understand the implied meaning in speech partners' speech and were able to implement politeness. A good understanding of language and context can minimize misunderstandings when communicating to avoid conflict. Through the implementation of politeness, there is a harmonious relationship between fellow students and between students and lecturers. This was stated by Student 36 (S36). "After studying pragmatics, speech acts, implications, and politeness, I can apply these pragmatic components in the learning process and this greatly affects the way I learn because I better understand what the teacher communicates to me. I am unambiguous and can maintain a harmonious relationship with the teacher based on polite and targeted communication according to the context." Student 64 (S64) further stated, "Dealing only with linguistic features such as traditional grammar and literal meaning of words will only encourage language learners to master the language not the use of language. henceforth, by mastering pragmatics language learner will improve their interpersonal skills."

After studying pragmatics, there were respondents motivated to develop sensitivity to the phenomena and sociocultural situations around them. Like Student 12 (S12) who argued that 
"[understanding pragmatics] not only understands it as the language, I learn but also understands and understands further about the socio-cultural context of the language I learned. That in interacting and building relationships with other people through 'language', there are many things that I have to pay attention to and take into account. "

In addition to having a positive influence on respondents in the process of learning English, pragmatics also influences respondents' perspectives on how to teach English. Respondents shared the results of their reflections on differences in teaching methods before and after studying pragmatics.

After understanding pragmatics, teachers become more selective in the choice and use of language. The selection and use of appropriate language also contribute to good social relations between teachers and students. Student 66 (S66) states that "after studying pragmatics, speech acts, implicatures, and politeness, I am more selective in choosing and using language. .... From using the right language, it will foster chemistry between speakers and listeners. Especially in teaching and learning activities, if the chemistry between students and teachers can be raised, the knowledge transfer process will run effectively. "

S27 shared his experience in applying some of these theories, "We as teachers can attract students 'attention more in terms of communication or can even develop students' mindsets so that they can be more sensitive to the environment. Even though we know that each student must have a different level of awareness. For example, whenever I teach a class and explain on the board I often say "Why I cannot use the marker?" because in reality, the markers ran out. Then some of them responded to fill in markers into the administration office. "

Teachers' understanding of pragmatics will contribute to the development of new perspectives for students that learning English is not just textual learning but also contextual learning. This has implications for the possibility of the teacher raising contextual subjects around him when teaching English. This was conveyed by Student 72 (S72) "It needs to be made aware of students so that in conversations using flexible communicative maxims, not grammatically correctness-oriented with free topics, the choice of students (not always determined by the teacher) in textbooks. . "

Furthermore, respondents think that by implementing pragmatic science in learning will internalize the values of politeness in students. In carrying out their role as teachers, respondents can be good role models for their students, thereby generating student respect for the teacher. This respectful attitude is then manifested in a polite attitude related to the value of politeness in the theory of pragmatics. S5 states that "After studying about the pragmatic components, as a teacher should give the example of how someone communicates clearly and mind about the way we talk with for. I think to give reprimand when there is student speak in the wrong way. As we know that almost child in this era has less about attitude especially with the older people. " Then there was Student 16 (S16) who briefly touched on the wise attitude in social media, the following was the answer S16 "In my opinion, the field of Pragmatics give me a very large scope dealing with communication. As a student, I become interested and enlightened to study how people make meanings in their utterances. As an English teacher, I become more aware the power of meanings I will use when interacting with my students, or instead, I could raise my students' awareness to communicate wisely, particularly in the use of social media."

4.3 The effect of pragmatics, speech act, implicature and politeness on the way respondents communicate daily.

Communication is something that cannot be separated from human life. Communication is carried out by humans to convey certain messages. In communicating, humans play the role of 
communicators and communicants. To carry out its role properly, pragmatics is needed as a guide in speaking according to the surrounding situation. Besides, pragmatics also becomes a guide in interpreting the speech of others. By understanding and implementing pragmatic science, respondents are equipped to communicate effectively. This was conveyed by Student 36 (S36), Student 58 (S58), and Student 71 (S71). S36 said that "after studying pragmatics, speech acts, implicatures, and politeness, it affects the way I communicate daily as I can achieve my communication goals with the interlocutor clearly without ambiguity by paying attention to the proper context of speech and communicating politely so that it has a positive impact on all parties without any party feeling aggrieved." There is a student who claims that he has applied pragmatics without realizing it, following the answer to S58 he says, "Without realizing it, it turns out that I have been implementing these four things so far, and did not know that what I was doing had a long-discovered theory. By knowing pragmatics, speech acts, implicatures, and politeness, I can find many examples in everyday life when communicating. That way I came to understand that acting in speech cannot be as we wish. We can't always be what we expect. The way of communicating also has rules. By following the rules of language, communication harmony will be created well and will make us more easily accepted by others wherever we are. In addition, I feel that I can be more careful in responding to other people's conversations to maintain comfort in communicating. (Unconsciously having applied these four things before studying, adding to the treasury of science to be able to classify speech acts, implicatures and values of politeness that exist in everyday speech). "

There is also S71 which explains the impact of pragmatics in the context of everyday life systematically, he explains that "after knowing more deeply about the things above, as a person, this will greatly affect me in the future in my daily communication. It influences me to think before speaking, know the place and context in which I am and should speak, and be selective in issuing utterances that are following the environment and context of the conversation. As a listener or receiver of information (receiver), this will also affect me in processing the information I receive, according to what I have learned. So, it is hoped that a balance can occur as a speaker and recipient of information, as well as resulting in the expected communication according to the objectives."

\section{Conclusions}

Most of the respondents in this study considered pragmatics an important provision in language learning for both students and teachers. By studying pragmatics, the relationship between individuals with social can be well-intertwined by paying attention to the values that exist in everyday life. Pragmatics is also considered capable of being a bridge so that a language learner can improve his language skills by analyzing the phenomena that occur around them without having to look too much for what subject can be used as learning material.

\section{References}

1. Pratama H, Rokhman F, Urip SR. Conversational implicature comprehension strategies used by English learners in Indonesia* 10. 언어연구. 2019;36(3):415-58.

2. Yule G. Pragmatics. Revised Ed. New York: Oxford University Press; 1998.

3. Kasper $\mathrm{G}$. The role of pragmatics in language teacher education. Beyond Methods Components Second Lang Teach Educ. 1997;113-36.

4. Griffiths P. Introduction to English semantics and pragmatics. Edinburgh: Edinburgh University Press; 2006.

5. Yule G, Stalnaker R. Pragmatics. Synthese. 1996;22:152. 
6. Austin JL. How to do things with words. Oxford: Oxford University Press; 1962.

7. Searle JR. A classification of illocutionary acts. Lang Soc. 1976;1-23.

8. Horn LR, Ward G. The handbook of pragmatics. Maiden: Blackwell Publishing; 2006.

9. Grundy P. Doing pragmatics. New York: Routledge; 1995.

10. Brown P, Levinson SC. Politeness: Some universal in language usage. New York: Cambridge University Press; 1987.

11. Cruse A. A glossary of semantics and pragmatics. Edinburgh: Edinburgh University Press; 2006.

12. Mey JL. Pragmatics as deconstruction. Soc Semiot. 1993;3(2):219-30. 